\title{
Farmer's lung in a group of Scottish dairy farms
}

\author{
V. E. WARDROP, W. BLYTH AND I. W. B. GRANT \\ From the Experimental Mycoses Unit, Department of Botany, University of Edinburgh, Edinburgh, \\ EH9 $3 J H$ and Respiratory Unit, Northern General Hospital, Edinburgh, EH5 2DQ
}

ABSTRACT The microbiology of the air of byres and bruising sheds and of hay, grain and dust from bruising machines was studied in 12 dairy farms in Ayrshire and one in Perthshire. Seven farms (FLD) had a known case of farmer's lung disease and five farms (non-FLD) were free from the disease. Concentrations of mesophilic organisms and of thermotolerant and thermophilic fungi did not vary significantly between the two types of farm but the concentrations of thermophilic actinomycetes and bacteria, notably Micropolyspora faeni, were higher in general on FLD farms. Culture filtrate and mycelial extracts of the most commonly isolated organisms were tested against three groups of sera (11 from patients with farmer's lung disease, 14 from healthy personnel on FLD farms and 13 from personnel without farmer's lung disease on non-FLD farms). Only extracts from a Penicillium sp. and a Streptomyces sp. precipitated with a number of sera, when extracts from the 12 most commonly isolated fungi, from six thermophilic actinomycetes other than $M$. faeni and Thermoactinomyces vulgaris, and from two thermophilic bacteria were tested. There was no correlation between disease and seropositivity. All sera reacted to at least one of 60 carbol-saline and trichloracetic acid extracts from 30 samples of hay, grain and dust. Although sera from personnel on both FLD and non-FLD farms precipitated with $16 \%$ and $19 \%$ of these extracts respectively, reactivity to extracts from FLD farms was greater on average than to those from non-FLD farms. When tested by several serological methods against extracts of a type culture of $M$. faeni and by double diffusion against farmer's lung hay (FLH) and extracts of local isolates of $M$. faeni, $91 \%$ of all clinical cases of farmer's lung were serologically positive but no one test was adequate for determining sensitisation. Fifty-four per cent of sera from FLD and also from non-FLD farms were positive in at least one test. Sixty-nine per cent of seropositive personnel on FLD farms were also symptomatic. The occurrence of symptoms apparently correlated with the higher concentrations of $M$. faeni encountered on FLD farms.

The pilot survey by Grant et al. (1972) on farmer's lung disease in Scotland, reported prevalences of 86 and $23 / 1000$ of the farming populations surveyed. Ayrshire in the West of Scotland gave the higher of the two prevalences and was therefore chosen for intensive study. Farm products from this area also yielded higher numbers of thermophilic actinomycetes than equivalent samples from East Lothian which had the lower incidence of disease (Wardrop, 1974). The evidence that the antigens provoking disease occur in thermophilic actinomycetes, notably Micropolyspora faeni and to a lesser extent Thermoactinomyces vulgaris, is regarded as convincing (Pepys et al., 1962; Pepys and Jenkins, 1965;

Received for publication 11 October 1976

Accepted for publication 25 February 1977
Barbee et al., 1965). Sera from a variable number of patients are also known to contain precipitins to a range of fungi from genera such as Aspergillus, Penicillium, Cladosporium, Mucor and Humicola. The significance, if any, of these precipitins in relation to disease is obscure. The sources of respirable organic dusts containing antigens which induce extrinsic allergic alveolitis in the farm environment are products such as hay, grain and dust generated by bruising and milling machinery. The present investigations were undertaken to compare the microbiological components of farms with (FLD) and without (non-FLD) clinical cases of farmer's lung disease.

As little is known about the significance of the microbiology of Scottish farms in relation to respiratory disease, we hoped to relate the occurrence 
of commonly encountered mesophilic, thermotolerant and thermophilic organisms to the incidence of serum precipitins in diseased and healthy personnel. Additional studies involved the reactivity of sera to extracts from farm products.

The survey was carried out during March and April 1972 following a very good hay-making season and average grain harvest in 1971. The hay which was fed to animals had therefore been stored for eight to nine months and the grain for seven to eight months. Individuals working with these materials had been in contact with them and exposed to their antigenic content, if any, for a period of five to six months during the winter while feeding stock.

\section{Materials and methods}

\section{SAMPLING OF FARM ENVIRONMENTS AND} PRODUCTS

In Ayrshire, six dairy farms each with a known case of farmer's lung disease (FLD farms) and five dairy farms with no record of disease (non-FLD farms) in the six years previous to 1972 , were chosen for microbiological examination during March and April 1972. One Perthshire dairy farm with a known case of farmer's lung was also studied. The 12 farms were of equivalent size (100-210 acres) and similar in agricultural practice.

The air in dairy byres of five FLD farms (LM, SB, MH, KM and A) and five non-FLD farms (MF, MT, WH, BM and B) in Ayrshire was sampled before and approximately five minutes after hay unbaling and dairy cattle foddering. The air in bruising sheds of four FLD farms (SB, EM, KM and A) and four non-FLD farms (MF, WH, BM and B) was sampled before and approximately five minutes after barley bruising or hammer-milling had begun. Samples were taken from the dairy byre and bruising shed of the farm (BP) in Perthshire before and after hay unbaling and before and after oats bruising respectively.

For sampling, an eight-stage Andersen Sampler (Andersen, 1958) was run at an air flow of $25 \mathrm{l} / \mathrm{min}$ for periods of between five and 30 seconds. The apparatus was loaded with eight disposable $9 \mathrm{~cm}$ Petri dishes and sampled air in farm buildings before (time A) and after (time B) hay unbaling or grain bruising. At time $A$ the upper four plates (0-3) contained $2 \%$ malt agar (M) and the lower four, which had three compartments, contained half-strength nutrient broth (Oxoid) with $500 \mathrm{mg} / \mathrm{l}$ cycloheximide $(\mathrm{N}+\mathrm{C})$, glycerol asparaginate (GA) and tap water (TW) in $2 \%$ agar media. Two sets of eight plates were successively exposed at time B. One was a set of malt agar plates subsequently incubated at $26^{\circ} \mathrm{C}$, and the other was a set of three-compartment plates containing media as described above and incubated at $46^{\circ} \mathrm{C}$.

Samples of hay, whole grain, bruised or hammermilled grain and dust off bruising and milling machines were collected at the time of unbaling, bruising or milling. They were placed in weighed sterile four-litre tin cans and the weight of each sample was determined. By means of a length of stiff polythene tubing connected to a modified tin lid, each sample was attached in turn to the sampler and shaken vigorously on a Griffin flask shaker for $\mathbf{3 0}$ seconds. Air was pumped out of the tin over the plates in the sampler until all air containing propagules released from the sample was removed and the tin buckled. Of two sets of plates used to sample each product, one containing $2 \%$ malt agar was incubated at $26^{\circ} \mathrm{C}$; the other, consisting of three. compartment plates with media as described above, was incubated at $46^{\circ} \mathrm{C}$.

\section{COUNTING AND IDENTIFICATION OF}

\section{COLONIES OF FUNGI AND ACTINOMYCETES}

Total counts of colonies on all plates were made after $48 \mathrm{~h}$ according to the positive hole conversion and microscope method of Andersen (1958). Mesophilic fungi on malt plates were identified after seven to 10 days. Thermophilic fungi on GA plates were identified after four to five days, or were sub-cultured and grown for a further 10 to 14 days. The more common thermophilic actinomycetes were identified to generic level: Thermoactinomyces vulgaris and Micropolyspora faeni were identified using the criteria of Cross (1968) and Cross et al. (1968). The numbers of different types of culturable propagules isolated per cubic metre of air or per $10 \mathrm{~g}$ of hay, grain or dust were calculated.

\section{EXTRACTS FROM MICROORGANISMS}

Culture filtrate (CF) and mycelial (M) extracts were obtained from shake cultures of the fungi and actinomycetes most commonly found on both FLD and non-FLD farms. Fungi were grown in $\mathbf{4 0 0}$ $\mathrm{ml}$ aliquots of Czapek-Dox (Oxoid) containing $2 \mathrm{~g}$ Nutrient Broth (Oxoid) in litre flasks shaken in darkness in an orbital incubator. Mesophilic fungi were grown for six weeks at $26^{\circ} \mathrm{C}$, thermophilic and thermotolerant fungi for three weeks at $46^{\circ} \mathrm{C}$. Thermophilic actinomycetes were grown under similar conditions for three weeks at $46^{\circ} \mathrm{C}$ in nutrient broth containing $1 \%$ glucose. Culture filtrate and mycelial fractions were obtained as shown in Figure 1.

EXTRACTS FROM HAY, GRAIN AND DUST

Samples of $5 \mathrm{~g}$ hay or dust and of $10 \mathrm{~g}$ whole or 


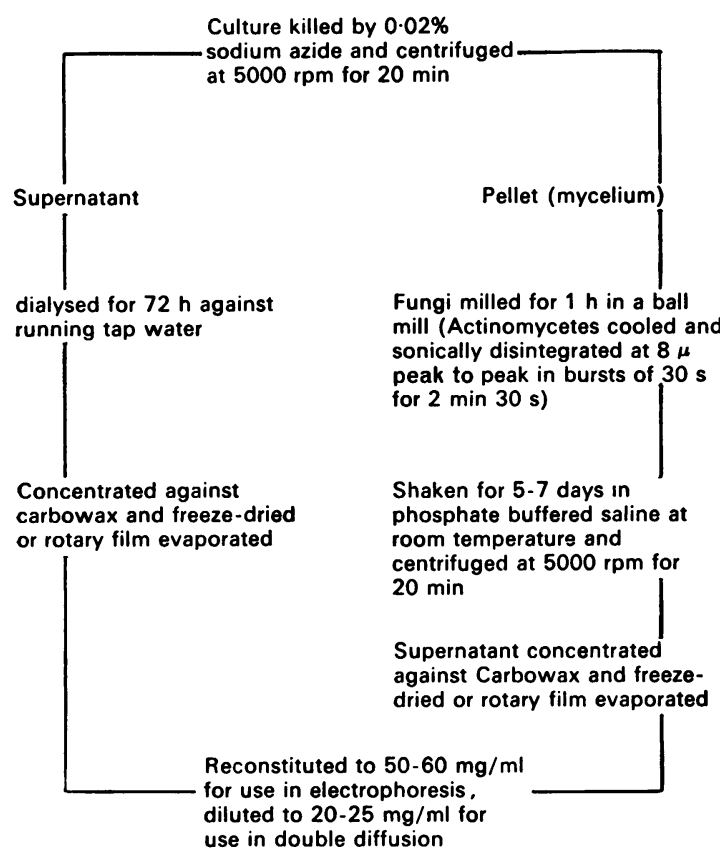

Fig. 1 Flow chart of antigen extraction from fungi and actinomycetes.

processed grain were placed in litre screw-topped jars. The samples were defatted in $200 \mathrm{ml}$ acetone overnight and after decanting, the acetone was passed through muslin to retain any large particles. Two hundred $\mathrm{ml}$ of Coca's solution were added to each of the samples and the jars were shaken in an orbital incubator for seven days at $26^{\circ} \mathrm{C}$. Filtered solutions were dialysed for $72 \mathrm{~h}$ against running tap water, concentrated against polyethylene glycol 4000 and dried by rotary evaporation. The product was reconstituted, by addition of distilled water, to a concentration of $20-25 \mathrm{mg} / \mathrm{ml}$ for use in double diffusion tests and $50-60 \mathrm{mg} / \mathrm{ml}$ for use in immunoelectrophoresis.

Samples of $5 \mathrm{~g}$ hay or dust and of $10 \mathrm{~g}$ whole or processed grain were placed in litre screw-topped jars. After $200 \mathrm{ml} \mathrm{5 \%}$ trichloracetic acid (TCA) had been added to each sample, they were shaken for three days in an orbital incubator at $26^{\circ} \mathrm{C}$. Further processing was as described above for extraction using Coca's solution.

FARMER'S LUNG HAY ANTIGEN (FLH)

This was supplied by the Public Health Laboratory Service.

\section{SEROLOGY}

Blood samples $(20 \mathrm{ml})$ were obtained from farmers, farm workers and farmers' wives actively involved



Fig. 2 The number of colonies of mesophilic organisms $\times 10^{-6}$ isolated per $m^{3}$ of air from dairy byres after unbaling hay (I), and from bruising sheds after bruising grain (2).

in work on nine FLD and five non-FLD farms. Two positive sera, one (B) from a patient in Perthshire and one (C) from a patient in Ayrshire were obtained from hospital clinics. Sera from a total of 11 FLD cases, 14 non-FLD personnel on FLD farms and 13 non-FLD personnel on non-FLD farms were tested. A control group of 50 sera was obtained from the Blood Transfusion Service, Edinburgh.

Double diffusion (DD) in agar was carried out as described by Ouchterlony (1953). Immunoelectrophoresis (IE) was by the method of Pepys and Jenkins (1965) and the numbers of arcs of precipitation were classified accordingly. Immunoelectroosmophoresis (IEO) was conducted according to the method of Gordon et al. (1971).

\section{Results}

\section{ORGANISMS IN THE AIR OF FARM}

\section{BUILDINGS}

After hay unbaling and grain bruising, more mesophilic organisms were found per $\mathrm{m}^{3}$ of air than before. With four exceptions, the concentrations of thermophilic actinomycetes and bacteria were also higher after unbaling and bruising than before. There was considerable variation in the numbers of colonies of mesophiles (Fig. 2) isolated from dairy byres on FLD farms, but the numbers from all non-FLD dairy byres were of approximately the same magnitude, intermediate to the values obtained from the air of FLD dairy byres. Although the 


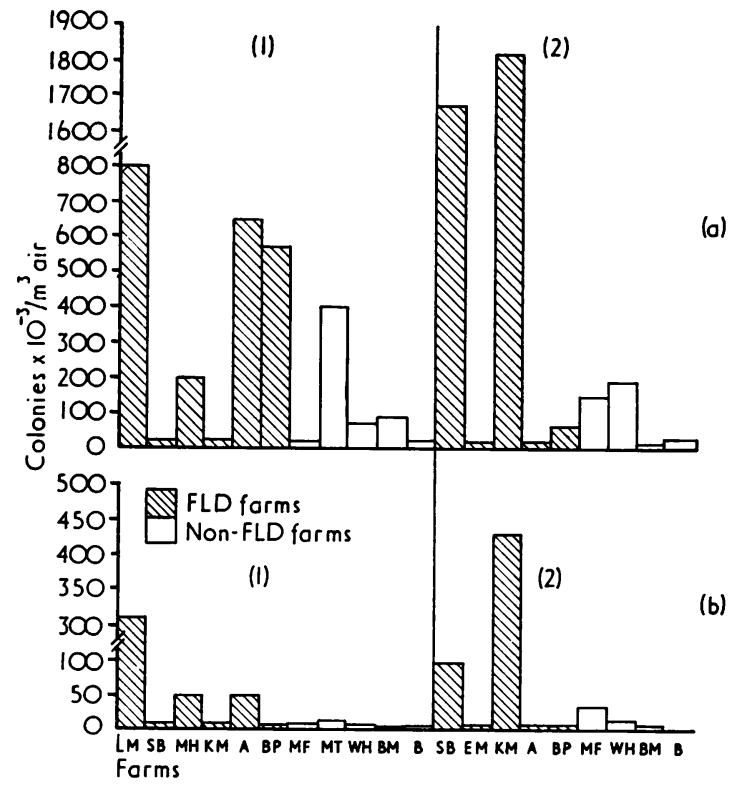

Fig. 3 The number of colonies of thermophilic actinomycetes and bacteria (a) and of M. faeni (b) $\times 10^{-3}$ isolated per $m^{3}$ of air from dairy byres after unbaling hay (1), and from bruising sheds after bruising grain (2).

highest level in dairy byres was $5418 \times 10^{3} / \mathrm{m}^{3}$, values of between $8000 \times 10^{3}$ and $88861 \times 10^{3} / \mathrm{m}^{3}$ were recorded in five bruising sheds.

The corresponding results for thermophilic actinomycetes and bacteria are shown in Fig. 3(a). It is notable that in four of the 11 dairy byres sampled, high values of between $402 \times 10^{3}$ and 796 $\times 10^{3} / \mathrm{m}^{3}$ were recorded, but only one high value was from a non-FLD farm (MT). Two FLD farms, however, yielded very high counts of $1663 \times 10^{3}$ and $1811 \times 10^{3} / \mathrm{m}^{3}$ from the air of their bruising sheds, while all counts from non-FLD farms were relatively low. The results for $M$. faeni are shown in Fig. 3(b). Values above $45 \times 10^{3}$ propagules $/ \mathrm{m}^{3}$ were recorded only on FLD farms with a maximum of $427 \times$ $10^{3} / \mathrm{m}^{3}$ for the bruising shed of farm KM. These results suggest that significantly higher levels of $M$. faeni are found on FLD farms. T. vulgaris was less common than $M$. faeni, the highest value being $57 \times 10^{3} / \mathrm{m}^{3}$ from the dairy byre of farm $A$ and in only three of the bruising-sheds of nine farms was any value recorded, the maximum being $7 \times 10^{3} / \mathrm{m}^{3}$. Thermophilic fungi showed a highest count of 457 $\times 10^{3} / \mathrm{m}^{3}$ in the dairy byre of farm A. Only two bruising sheds, compared with four dairy byres, had values of between $30 \times 10^{3}$ and $79 \times 10^{3} / \mathrm{m}^{3}$.

\section{SPECIES AND GROUPS OF ORGANISMS}

ISOLATED

The mesophilic groups and species of fungi isolated from the air of farm buildings and from samples of hay, grain and dust were as follows: Absidia spp., Acremoniella atra, Alternaria spp., Aspergillus candidus, A. flavus, A. fumigatus*, A. glaucus*, A. nidulans*, A. niger, A. ochraceus, A. ornatus, A. restrictus*, A. terreus*, A. ustus, A. versicolor*, Aureobasidium pullulans, Botryotrichum spp., Botrytis cinerea, Chaetomium spp., Chrysosporium spp., Cladosporium spp.*, Doratomyces sp., Epicoccum nigrum, Fusarium spp., Geotrichum spp., Mucor spp., Mycelia sterilia, Paecilomyces spp., Penicillium spp.*, Rhizopus spp.*, Scopulariopsis spp., Sporothrix sp., Trichoderma viride, Trichothecium roseum, Verticillium spp. and Yeasts. Species marked * were used for serological testing. The Aspergilli were divided into the collective Groups described by Raper and Fennell (1965).

Thermophilic and thermotolerant fungal species and groups comprised A. fumigatus, Humicola spp., and Mucorales. Those used for serology were two strains of the A. fumigatus Group, a thermophilic Humicola sp. and Mucor pusillus. Commonly isolated thermophilic actinomycetes included Saccharomonospora viridis (Nonomura and Ohara, 1971), Streptomyces spp., Thermoactinomyces vulgaris and Micropolyspora faeni. Organisms extracted for serology were six isolates of $M$. faeni from different farms, four isolates of a variant of $M$. faeni, five Streptomyces spp., one isolate of $S$. viridis, one isolate of $T$. vulgaris, an isolate of Bacillus cereus var. mycoides and one of a Gramnegative thermophilic bacterium. Culture filtrate and mycelial extracts were also prepared from Type cultures of $M$. faeni and $T$. vulgaris.

SEROLOGICAL REACTIONS TO MICROORGANISMS OTHER THAN $M$. FAENI AND T. VULGARIS

Table 1 shows all positive reactions between 36 FLD and non-FLD sera and CF and $M$ extracts from a range of fungi and two thermophilic Streptomyces spp. Extracts from only two organisms reacted widely within all groups of sera; the $M$ extract of the Penicillium sp. and the CF extract of a white, thermophilic Streptomyces sp. reacted to a total of 10 and 14 sera respectively. There was no correlation between FLD and reactions to any of the organisms tested.

SEROLOGICAL REACTIONS TO EXTRACTS OF HAY, GRAIN AND DUST

Results are summarised in Tables 2 and 3. Of the sera tested to both Coca and TCA extracts of hay 
Table 1 Positive reactions of 36 sera to culture filtrate $(C F)$ and mycelial $(M)$ extracts of microorganisms

\begin{tabular}{|c|c|c|c|c|c|c|c|c|c|c|c|c|c|c|c|c|}
\hline \multicolumn{2}{|l|}{ Serum } & \multicolumn{8}{|c|}{ Mesophilic fungi } & \multicolumn{5}{|c|}{ Thermophilic fungi } & \multicolumn{2}{|c|}{ Actinomycetes } \\
\hline Group & No. & $\begin{array}{l}\text { Rhiz. } \\
\text { CF }\end{array}$ & $\begin{array}{l}\text { Clad. } \\
C F\end{array}$ & $\begin{array}{l}\text { Pen. } \\
M\end{array}$ & $\begin{array}{l}\text { Asp.f. } \\
\text { (i) } \\
C F\end{array}$ & $\begin{array}{l}\text { Asp.t. } \\
M\end{array}$ & $\begin{array}{l}\text { Asp.n. } \\
M\end{array}$ & $\begin{array}{l}\text { Asp.r. } \\
M\end{array}$ & $\begin{array}{l}\text { Asp.v. } \\
C F\end{array}$ & $\begin{array}{l}\text { Asp.f. } \\
\text { (ii) } \\
C F\end{array}$ & $\begin{array}{l}\text { Asp.f. } \\
\text { (ii) } \\
M\end{array}$ & $\begin{array}{l}\text { Asp.f. } \\
\text { (iii) } \\
M\end{array}$ & $\begin{array}{l}\text { Hum. } \\
M\end{array}$ & $\begin{array}{l}\text { Mucor } \\
M\end{array}$ & $\begin{array}{l}103 \\
C F\end{array}$ & $\begin{array}{l}309 \\
C F\end{array}$ \\
\hline FLD & $\begin{array}{r}2 \\
21 \\
28 \\
\text { B } \\
\text { C }\end{array}$ & & & $\begin{array}{l}+ \\
+ \\
+\end{array}$ & & + & + & + & & & & $\begin{array}{l}+ \\
+\end{array}$ & + & + & $\begin{array}{l}+ \\
+ \\
+\end{array}$ & \\
\hline $\begin{array}{l}\text { Non- } \\
\text { FLD } \\
\text { on FLD } \\
\text { farms }\end{array}$ & $\begin{array}{r}1 \\
8 \\
9 \\
11 \\
12 \\
27 \\
29 \\
30 \\
32 \\
33\end{array}$ & + & + & + & + & & & & & & & & & & $\begin{array}{l}+ \\
+ \\
+ \\
+ \\
+ \\
+\end{array}$ & \\
\hline $\begin{array}{l}\text { Non- } \\
\text { FLD on } \\
\text { non- } \\
\text { FLD } \\
\text { farms }\end{array}$ & $\begin{array}{r}3 \\
4 \\
5 \\
6 \\
14 \\
17 \\
25\end{array}$ & & & $\begin{array}{l}+ \\
+ \\
+ \\
+\end{array}$ & & & & & + & + & + & & & + & $\begin{array}{l}+ \\
+ \\
+ \\
+ \\
+\end{array}$ & + \\
\hline
\end{tabular}

Rhiz. = Rhizopus sp.; Clad. = Cladosporium sp.; Pen. = Penicillium sp.; Asp.f. = Aspergillus fumigatus; Asp.t. = Aspergillus terreus; Asp.n. = Aspergillus nidulans; Asp.r. = Aspergillus restrictus; Asp.v. = Aspergillus versicolor; Hum. = Humicola sp.; Mucor $=$ Mucor sp.; $103=$ White thermophilic actinomycete; $309=$ Brown thermophilic actinomycete; (i) $=$ Mesophilic grown at $26^{\circ} \mathrm{C}$; (ii) $=$ Thermotolerant grown at $46^{\circ} \mathrm{C}$ (strain 1); (iii) = Thermotolerant grown at $46^{\circ} \mathrm{C}$ (strain 2); FLD = Farmer's lung disease.

Table 2 The microbiology of hay samples in relation to serology

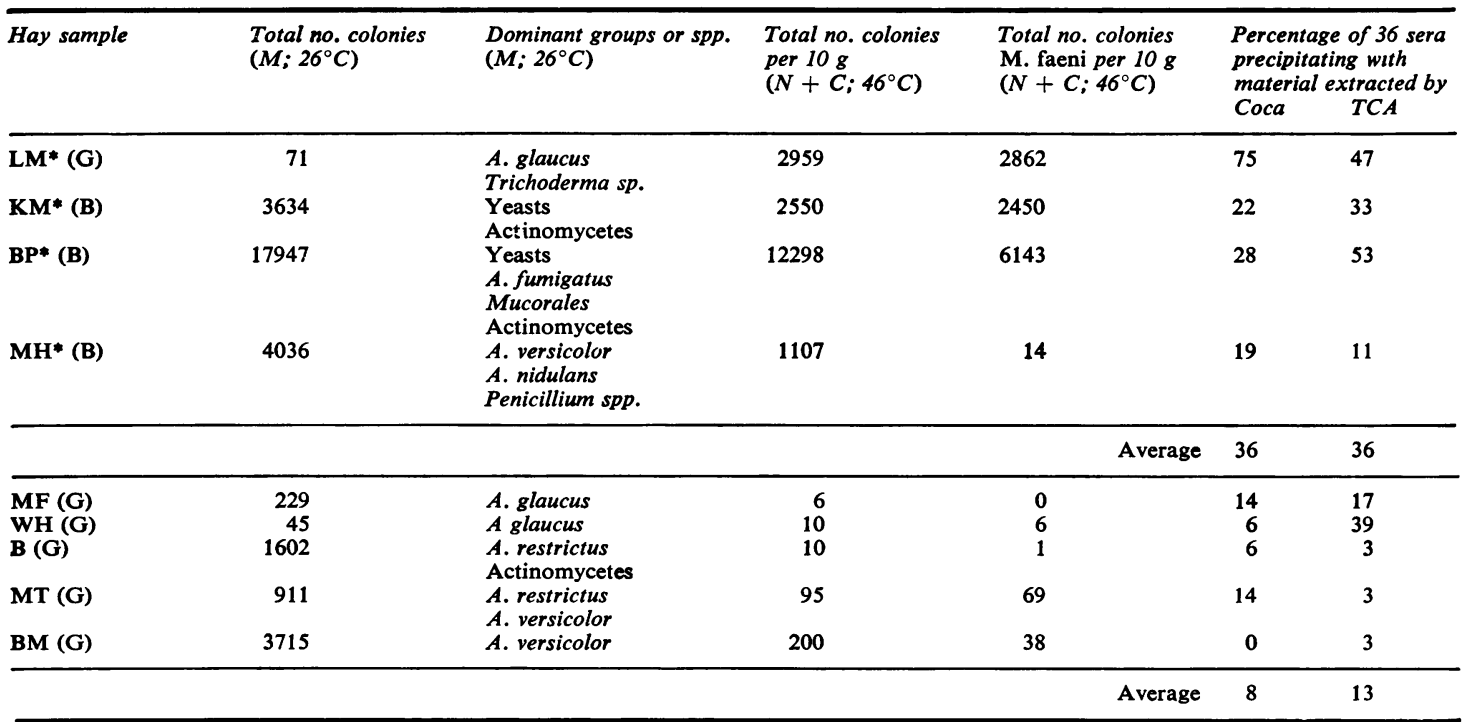

$M=$ malt agar $\mathbf{N}+\mathbf{C}=$ nutrient agar containing cycloheximide; Coca $=$ Coca's solution; $\mathbf{T C A}=$ trichloracetic acid; $*$ = sample from FLD farm; $(B)=$ visually bad; $(G)=$ visually good.

from FLD farms, on average $36 \%$ were positive whereas only $8 \%$ and $13 \%$ respectively were positive to similar extracts from hay collected on non-FLD farms. Reactivity largely correlated with high values for total colonies of thermophilic organisms and of $M$. faeni but was not related to total numbers of colonies of mesophiles. Similar but less marked differences between extracts from FLD and non- 
Table 3 The microbiology of whole barley, processed barley and dust samples in relation to serology

\begin{tabular}{|c|c|c|c|c|c|c|}
\hline \multirow{2}{*}{$\begin{array}{l}\text { Sample } \\
\text { Whole barley }\end{array}$} & \multirow[t]{2}{*}{$\begin{array}{l}\text { Total no. colonies } \\
\left(M ; 26^{\circ} \mathrm{C}\right)\end{array}$} & \multirow[t]{2}{*}{$\begin{array}{l}\text { Dominant groups or } \\
\text { species }\left(M ; 26^{\circ} \mathrm{C}\right)\end{array}$} & \multirow[t]{2}{*}{$\begin{array}{l}\text { Total no. } \\
\text { colonies } 110 \mathrm{~g} \\
\left(N+C ; 46^{\circ} \mathrm{C}\right)\end{array}$} & $\begin{array}{l}\text { Total no. colonies } \\
\text { M. faeni } \\
\left(N+C ; 46^{\circ} C\right)\end{array}$ & \multicolumn{2}{|c|}{$\begin{array}{l}\text { Percentage of } 36 \text { sera } \\
\text { precipitating with } \\
\text { material extracted by } \\
\text { Coca TCA }\end{array}$} \\
\hline & & & & & & \\
\hline $\begin{array}{l}\mathbf{S B}^{*} \\
\mathbf{K} \mathbf{M}^{*}\end{array}$ & $\begin{array}{l}5359 \\
2556\end{array}$ & $\begin{array}{l}\text { Penicillium spp. } \\
\text { A. candidus } \\
\text { Actinomycetes }\end{array}$ & $\begin{array}{r}802 \\
2334\end{array}$ & $\begin{array}{r}618 \\
1821\end{array}$ & $\begin{array}{l}31 \\
47\end{array}$ & $\begin{array}{r}17 \\
6\end{array}$ \\
\hline $\mathbf{E M} *$ & 7076 & $\begin{array}{l}\text { Penicillium spp. } \\
\text { Yeasts }\end{array}$ & 271 & 1 & 11 & 22 \\
\hline \multirow[t]{2}{*}{$\begin{array}{l}\mathrm{A}^{*} \\
\mathrm{BP} * \text { (oats) }\end{array}$} & $\begin{array}{r}28 \\
509\end{array}$ & $\begin{array}{l}\text { Yeasts } \\
\text { Penicillium spp. } \\
\text { Yeasts }\end{array}$ & $\begin{array}{r}5 \\
179\end{array}$ & $\begin{array}{r}1 \\
13\end{array}$ & $\begin{array}{l}3 \\
3\end{array}$ & $\begin{array}{l}3 \\
0\end{array}$ \\
\hline & & & & Average & 19 & 10 \\
\hline $\begin{array}{l}\text { WH } \\
\text { B }\end{array}$ & $\begin{array}{r}5 \\
2273\end{array}$ & $\begin{array}{l}\text { Yeasts } \\
\text { Penicillium spp. } \\
\text { Geotrichum sp. } \\
\text { Yeasts }\end{array}$ & $\begin{array}{l}125 \\
160\end{array}$ & $\begin{array}{l}60 \\
46\end{array}$ & $\begin{array}{r}14 \\
3\end{array}$ & $\begin{array}{l}6 \\
6\end{array}$ \\
\hline \multirow[t]{2}{*}{ MF } & 5796 & $\begin{array}{l}\text { Penicillium spp. } \\
\text { Yeasts }\end{array}$ & 8 & 0 & 8 & 3 \\
\hline & & & & Average & 8 & 5 \\
\hline \multicolumn{7}{|c|}{ Processed barley } \\
\hline \multirow[t]{2}{*}{$\mathbf{E M}^{*}$} & $\begin{array}{r}11781 \\
2250 \\
21\end{array}$ & $\begin{array}{l}\text { Penicillium spp. } \\
\text { Bacteria } \\
\text { Yeasts } \\
\text { Geotrichum sp. }\end{array}$ & $\begin{array}{r}1576 \\
132 \\
3\end{array}$ & $\begin{array}{r}1182 \\
40 \\
0\end{array}$ & $\begin{array}{r}3 \\
3 \\
33\end{array}$ & $\begin{array}{l}\mathbf{0} \\
\mathbf{3} \\
\mathbf{0}\end{array}$ \\
\hline & & & & Average & 13 & 1 \\
\hline MF & 3384 & $\begin{array}{l}\text { Penicillium spp. } \\
\text { Geotrichum sp. } \\
\text { Paecilomyces spp. }\end{array}$ & 1 & $\mathbf{0}$ & 3 & 0 \\
\hline \multirow[t]{2}{*}{ B } & 4355 & $\begin{array}{l}\text { Geotrichum sp. } \\
\text { Bacteria }\end{array}$ & 21 & 0 & 3 & 0 \\
\hline & & & & Average & 3 & 0 \\
\hline \multicolumn{7}{|l|}{ Dust } \\
\hline $\begin{array}{l}\mathbf{S B}^{*} \\
\mathbf{E M ^ { * }} \\
\mathbf{K} \mathbf{M}^{*} \\
\mathbf{A}^{*} \\
\mathbf{B P}^{*}\end{array}$ & $\begin{array}{r}1689 \\
2 \\
54 \\
28 \\
2\end{array}$ & $\begin{array}{l}\text { Yeasts } \\
\text { Penicillium spp. } \\
\text { Actinomycetes } \\
\text { Penicillium spp. } \\
\text { Penicillium spp. }\end{array}$ & $\begin{array}{r}430 \\
239 \\
46 \\
20 \\
6\end{array}$ & $\begin{array}{r}73 \\
0 \\
28 \\
1 \\
0\end{array}$ & $\begin{array}{r}42 \\
28 \\
28 \\
25 \\
6\end{array}$ & $\begin{array}{r}6 \\
33 \\
14 \\
0 \\
6\end{array}$ \\
\hline $\mathbf{B P}^{*}$ & & & & Average & 26 & 12 \\
\hline $\begin{array}{l}\text { MF } \\
\text { WH }\end{array}$ & $\begin{array}{r}16 \\
874\end{array}$ & $\begin{array}{l}\text { Geotrichum sp. } \\
\text { Penicillium spp. } \\
\text { Yeasts }\end{array}$ & $\begin{array}{r}26 \\
2\end{array}$ & $\begin{array}{l}0 \\
1\end{array}$ & $\begin{array}{r}6 \\
39\end{array}$ & $\begin{array}{r}6 \\
17\end{array}$ \\
\hline B & 6713 & $\begin{array}{l}\text { Yeasts } \\
\text { Penicillium spp. } \\
\text { Geotrichum sp. }\end{array}$ & 27 & 4 & 47 & 11 \\
\hline
\end{tabular}

Average $\quad 31 \quad 11$

$M=$ malt agar; $N+C=$ nutrient agar containing cycloheximide; Coca $=$ Coca's solution; TCA $=$ trichloracetic acid; ${ }^{*}=$ sample fro $m$ FLD farm.

FLD farms were obtained for whole barley samples. The effect of processing was demonstrated by the very low reactivity of extracts from processed barleys. Extracts from dusts, however, reacted more frequently with sera than those from whole barley on both FLD and non-FLD farms.

Table 4 shows that all sera were precipitinpositive to at least one of 60 extracts (Coca and
TCA) of 30 samples of hay, grain and dust. A larger percentage of sera from non-FLD farms was positive to a higher number of extracts than in the other 2 groups. Non-FLD sera from FLD farms reacted to the lowest number of extracts. It was calculated that on average sera from FLD farms reacted to $16 \%$ of all extracts whereas sera from non-FLD farms reacted to $19 \%$. Twenty-three 
Table 4 Percentage sera positive to extracts of hay, grain and dust in relation to positivity to $M$. faeni

\begin{tabular}{|c|c|c|c|c|c|c|}
\hline \multirow{2}{*}{$\begin{array}{l}\text { Number of extracts from } \\
\text { hay, grain and dust with } \\
\text { which sera reacted }\end{array}$} & \multicolumn{3}{|c|}{ Percentage sera positive to hay, grain and dust } & \multicolumn{3}{|c|}{ Percentage sera positive to $\mathrm{M}$. faeni } \\
\hline & $\begin{array}{l}F L D \\
(10)\end{array}$ & $\begin{array}{l}\text { non-FLD on } \\
F L D \text { farms } \\
\text { (14) }\end{array}$ & $\begin{array}{l}\text { non-FLD on } \\
\text { non-FLD farms } \\
\text { (12) }\end{array}$ & $\begin{array}{l}F L D \\
(11)\end{array}$ & $\begin{array}{l}\text { non-FLD on } \\
F L D \text { farms } \\
\text { (14) }\end{array}$ & $\begin{array}{l}\text { non-FLD on } \\
\text { non-FLD farms } \\
\text { (13) }\end{array}$ \\
\hline 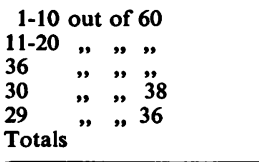 & $\begin{array}{r}80 \\
0 \\
10 \\
0 \\
10 \\
100\end{array}$ & $\begin{array}{r}93 \\
7 \\
0 \\
0 \\
0 \\
100\end{array}$ & $\begin{array}{r}59 \\
33 \\
0 \\
8 \\
0 \\
100\end{array}$ & $\begin{array}{r}64 \\
0 \\
9 \\
0 \\
9\end{array}$ & $\begin{array}{r}28 \\
0 \\
0 \\
0 \\
0\end{array}$ & $\begin{array}{c}7.5 \\
31 \\
0 \\
7.5 \\
0\end{array}$ \\
\hline \multicolumn{4}{|c|}{ Not tested to hay, grain and dust, but to $M$. faeni } & 9 & & $7 \cdot 5$ \\
\hline \multicolumn{4}{|l|}{ Totals } & 91 & 28 & 54 \\
\hline
\end{tabular}

Table 5 The reactions of 38 sera to farmer's lung hay $(F L H)$ antigen and to antigens from a type culture and local Ayrshire isolates of M. faeni

\begin{tabular}{|c|c|c|c|c|c|c|c|c|c|c|}
\hline \multirow{2}{*}{$\begin{array}{l}\text { Serum } \\
\text { reaction } \\
\text { category }\end{array}$} & \multicolumn{3}{|c|}{ No. and sources of sera } & \multirow[t]{2}{*}{$I E$} & \multicolumn{4}{|c|}{ Double diffusion } & \multirow[t]{2}{*}{$I F A T$} & \multirow[t]{2}{*}{ IEO } \\
\hline & $F L D$ & $\begin{array}{l}\text { Non-FLD on } \\
\text { FLD farms }\end{array}$ & $\begin{array}{l}\text { Non-FLD on } \\
\text { non-FLD farms }\end{array}$ & & $F L H$ & $\begin{array}{l}\text { Type } \\
\text { M. faeni }\end{array}$ & Local 1 & aeni & & \\
\hline 1 & 3 & & 3 & $\begin{array}{l}\text { A, B, C } \\
\text { A, B, C } \\
\text { A, B, C } \\
\text { A, B } \\
\text { A, B, C } \\
\mathbf{A}, \mathbf{B}, \mathbf{C}\end{array}$ & $\begin{array}{l}+(3) \\
+(4) \\
+(6) \\
+(3) \\
+(6) \\
+(5)\end{array}$ & $\begin{array}{l}C F \\
+(2) \\
+(4) \\
+(4) \\
+(1) \\
+(4) \\
+(2)\end{array}$ & $\begin{array}{l}C F \\
+5 / 6 \\
\text { NT } \\
+6 / 6 \\
+2 / 6 \\
\text { NT } \\
+6 / 6\end{array}$ & $\begin{array}{l}M \\
\text { NT } \\
\text { NT } \\
+6 / 6 \\
+5 / 6 \\
\text { NT } \\
+6 / 6\end{array}$ & $\begin{array}{l}++ \\
\text { NT } \\
\text { NT } \\
++ \\
++ \\
++\end{array}$ & $\begin{array}{l}+ \\
+ \\
+ \\
+ \\
+\end{array}$ \\
\hline 2 & 3 & 1 & 3 & & $\begin{array}{l}+(1) \\
+(1) \\
+(1) \\
+(2) \\
+(1) \\
+(2)\end{array}$ & & $\begin{array}{l}+1 / 6 \\
+6 / 6 \\
+1 / 6 \\
+2 / 6\end{array}$ & $\begin{array}{l}+1 / 6 \\
+5 / 6 \\
+2 / 6 \\
+1 / 6 \\
+2 / 6 \\
+2 / 6\end{array}$ & $\begin{array}{l}+ \\
+ \\
+ \\
+ \\
+ \\
++\end{array}$ & \\
\hline 3 & 4 & 2 & 1 & $\mathbf{A}$ & $+(1)$ & & $+6 / 6$ & $+5 / 6$ & $\begin{array}{l}+ \\
+ \\
+ \\
+\end{array}$ & \\
\hline 4 & & 1 & & $\mathbf{A}$ & $+(1)$ & $+(1)$ & & & + & + \\
\hline Negative & 1 & 10 & 6 & & & & & & & \\
\hline
\end{tabular}

IE = immunoelectrophoresis; A, B and C = arcs of precipitation according to Pepys and Jenkins (1965); IEO = immunoelectroosmophoresis; IFAT $=$ indirect fluorescent antibody test $; \mathbf{C F}=$ culture filtrate; $\mathbf{M}=$ mycelial extract; (1) $=$ one precipitin arc formed; $1 / 6=$ one positive reaction to six extracts; NT = not tested; FLD = farmer's lung disease.

per cent of FLD sera reacted, as did $11 \%$ of nonFLD sera from personnel on FLD farms. Two FLD sera and one non-FLD serum reacted to $81 \%$, $60 \%$ and $79 \%$ respectively of extracts.

SEROLOGICAL REACTIONS TO FLH, M. FAENI AND T. VULGARIS

All reactions of sera to FLH and to antigens from the Type culture and strains of $M$. faeni are shown in Table 5. Four categories of positive sera were distinguished. Of the six strongly reactive sera comprising Category 1, all but one produced A, B and $\mathrm{C}$ arcs of precipitation in immunoelectrophoresis and also precipitated with extracts of the Type strain of $M$. faeni. A second category of seven sera, negative in IE and in tests with the $M$. faeni Type strain were positive to extracts from local strains of the organism. The seven sera comprising Category 3 were very weakly reactive, each giving a positive result in one test only. The single serum in Category 4 was weakly reactive in all tests except those involving local $M$. faeni isolates. There was a marked lack of reactivity in the sera from non-FLD personnel on FLD farms, 10 being negative for all tests 
Table 6 The serology of farmer's lung patients and controls in relation to the occurrence of M. faeni in farm environments, hay and grain

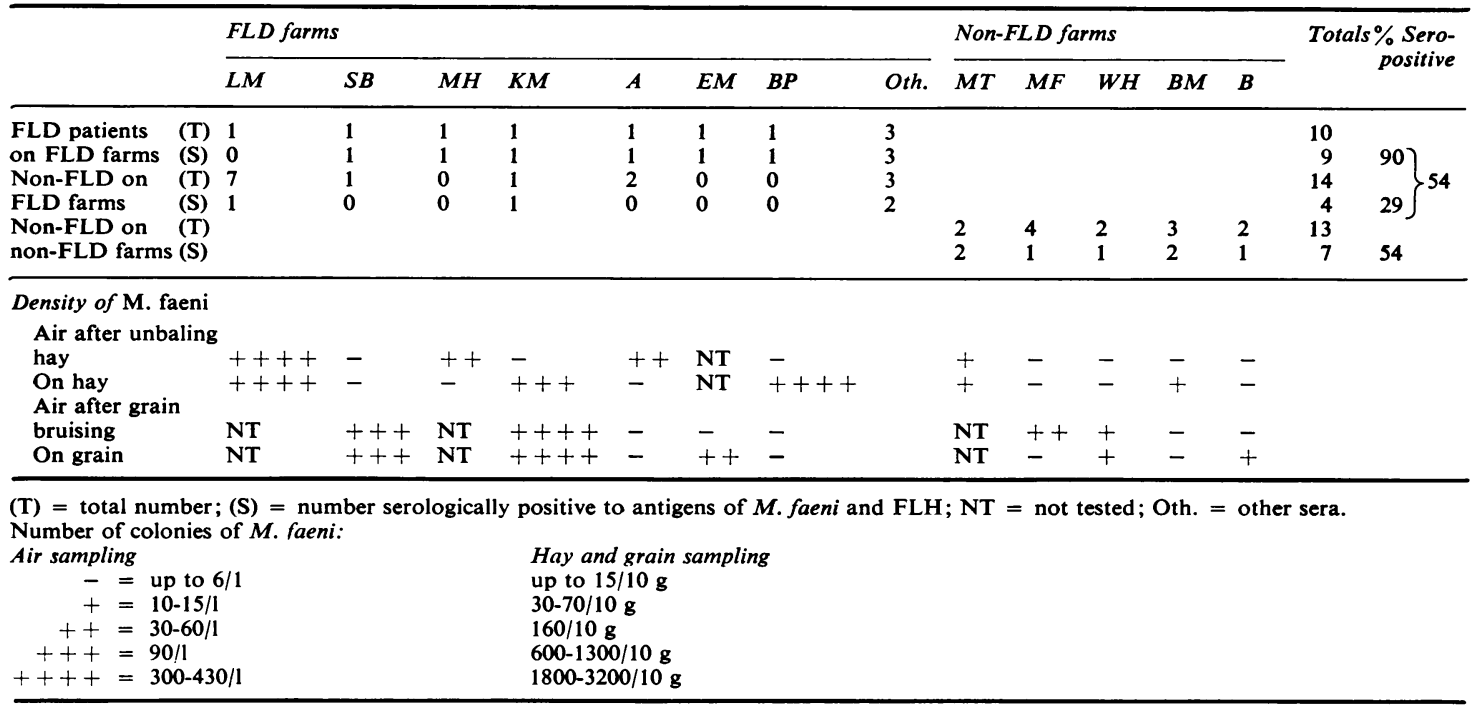

(Values for hay from $\mathrm{MH}, \mathrm{A}, \mathrm{KM}$ and BP are averages of two samples.)

out of 14. Although no sera reacted to the $M$ extract from the $T$. vulgaris Type culture, six reacted to the equivalent $\mathrm{CF}$ of this organism. Five of these six also produced between two and six arcs of precipitation with FLH. Neither $M$ nor CF extracts of an isolate of $T$. vulgaris from Ayrshire precipitated with sera.

\section{ENVIRONMENTAL HAZARD IN RELATION}

TO SEROLOGY

All FLD patients worked with both hay and grain. Hay alone was considered to be the main hazard by four patients, hay and grain together, by five and grain alone by the remaining two. Four blamed shovelling or bagging of grain in bulk at harvest time for their symptoms and five blamed bruising or milling stored grain. There was no correlation between the alleged hazards and serological reactivity of individuals to extracts of hay, grain and dust, or to those of $M$. faeni or T. vulgaris.

Of 14 non-FLD personnel on FLD farms, three were rarely in contact with hay or grain, 10 were regularly in contact with hay, five were regularly involved in bruising or milling grain and six were regularly in contact with grain only when feeding cattle. Of the 13 personnel on non-FLD farms, 12 were regularly in contact with hay, and four were regularly involved in bruising or milling grain. Three more occasionally bruised or milled grain while four were in contact with grain only when feeding animals. There was no correlation between the degree of serological reactivity of non-FLD personnel and their contact with hay or grain.

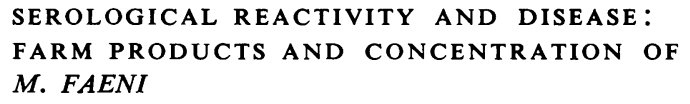

The numbers of thermophilic actinomycetes and bacteria isolated per $\mathrm{m}^{3}$ of air after unbaling and bruising were higher from FLD farms than from non-FLD farms (Fig. 3(a)). Table 6 shows that high concentrations of $M$. faeni were isolated from air or from hay or grain samples in four of seven FLD farms but no comparable results were obtained from non-FLD farms. Serological positivity recorded in Table 6 indicates reactivity to FLH and/or any test for $M$. faeni and the results include those for sera associated with the environments sampled as well as for an additional three FLD and three non-FLD sera from FLD farms. Ninety per cent of FLD subjects and $29 \%$ of non-FLD personnel on FLD farms were serologically positive, giving a figure of $54 \%$ positive for all personnel. Fifty four per cent of all individuals on non-FLD farms were also positive. The fact that $69 \%$ of all sensitised individuals on FLD farms were also symptomatic suggests that the large numbers of colonies of $M$. fueni isolated from FLD farms were instrumental in inducing disease. However, extracts of hay, grain and dust from such farms precipitated with a larger proportion of sera than did those from non-FLD farms; this indicates the presence of some additional 
reactive factors in the extracts, because reactivity did not correlate with that of $M$. faeni (Table 4). It is possible that ' $D$ line' antigen, possessing determinants in common with $\beta$-teichoic acids (Faux et al., 1970) may have been involved.

A notable but unexplained result is the remarkably low reactivity of sera from non-FLD personnel on FLD farms to FLH and extracts of farm products and $M$. faeni despite the high environmental concentrations of potentially antigenic propagules.

\section{Discussion}

Large concentrations of microorganisms were recovered from farm buildings after hay unbaling and grain bruising and from samples of these farm products. Although the concentrations of propagules released per unit fresh weight of hay were greater than for grain, the weight of grain processed in one bruising operation is generally greater than the weight of hay dealt with in one unbaling operation.

In general farm practice grain may be bruised every second or third day compared with twice-daily unbaling of hay, and the overall intake of respirable dust produced by the two processes over a period of weeks is possibly comparable, assuming that the materials are in an equivalent state of preservation. As the numbers of organisms recovered from samples of dust from bruising machinery were lower than expected, it is probable that a large proportion of propagules were dead but could still have been allergenic.

Thermophilic actinomycetes and bacteria, particularly $M$. faeni, were more common on farms where there was a case of farmer's lung than on those free from the disease. As no correlation could be established between concentrations of mesophilic organisms or of thermophilic fungi and the presence or absence of disease, these organisms may be considered to be of little significance. The results of serological tests, using extracts of the most common of these organisms confirmed this as few extracts, apart from those of a mesophilic Penicillium species, reacted with any of the groups of sera. Of the thermophilic actinomycetes other than $M$. faeni and $T$. vulgaris only one reacted with sera. The occurrence of precipitins to fungi was considerably lower than that reported by Pepys et al. (1963) and the results have clearly implicated thermophilic actinomycetes, particularly $M$. faeni, as the primary source of sensitising and/or disease-invoking antigens in the Scottish farming environment as in other similar environments in Great Britain. Although it is always assumed that high concentrations of $M$. faeni are necessary to provoke symptoms in sensitised individuals, little information has been made avail- able previously in terms of propagules per unit volume of air in the home environments of specific cases of farmer's lung.

Storage of farm products at too high an initial water content leads to self-heating and the subsequent growth of thermophilic organisms, resulting in the production of FLH antigen (Pepys et al., 1963; Festenstein et al., 1965). Most of the antigenic content of FLH has been shown to occur in extracts of $M$. faeni which also yield the A, B and C arcs of precipitation characteristic of FLH in immunoelectrophoresis (Pepys et al., 1963). It has been claimed that sera giving all three arcs are from patients having a history of frequent and severe attacks; Hollingdale and Murray (1974) found that sera from most severe cases cause precipitation of polysaccharide antigens in the $\mathrm{C}$ region. In the results reported here however two out of five sera giving $\mathbf{C}$ arcs of precipitation were from asymptomatic farmers. Pepys et al. (1962) noted that $80 \%$ of patients reacted to FLH, and Pepys and Jenkins (1965) quoted figures of $87 \%$ positive to extracts of $M$. faeni. In Scottish farms, however, Grant et al. (1972) recorded that only $43 \%$ of cases were positive. Hapke et al. (1968) established that $53 \%$ of patients in the chronic stage of disease were positive to $M$. faeni, compared with $100 \%$ in the acute stage. The validity of a positive test to FLH and extracts of $M$. faeni as a primary criterion in diagnosis has therefore been challenged (Grant et al., 1972; Morgan et al., 1973; Smyth et al., 1975). It is concluded from the Ayrshire results that a positive serological reaction indicates sensitisation with or without disease.

The numbers of healthy farmers with precipitins to antigens of $M$. faeni have been reported as none (Boyd, 1971), 15-21\% (Pepys and Jenkins, 1965) and $23 \%$ (Morgan et al., 1973). In the present study, $30 \%$ of healthy individuals reacted with FLH in double diffusion tests and only $55 \%$ of those with disease were also positive. After using extracts of $M$. faeni and the fluorescent antibody test however the figure for all patients became $91 \%$ and for all healthy individuals was $41 \%$. The use of a range of antigenic preparations from an isolate of $M$. faeni has been shown to be essential by Dick et al. (1973). Increased incidence of detection of antibody to $M$. faeni has been claimed using fluorescent antibody (Parratt and Peel, 1972; Boyd and Parratt, 1974) and radioimmunoassay (Parratt et al., 1975) techniques. The present work has established the value of using several isolates of $M$. faeni from local farm environments in preparing serological reagents.

In an area of known high incidence of farmer's lung in the West of Scotland, even after a very good hay-making season the degree of preservation of hay 
from FLD farms, as indicated by microbial evidence of self-heating, was generally not as good as that of hay from non-FLD farms. There was also an unexpectedly high percentage sensitisation of personnel on non-FLD farms to FLH and various $M$. faeni extracts. These results emphasise the need for efficient hay-making and preservation of grain combined with the judicious use of efficient respirators (Gourley and Braidwood, 1971) for protection against antigen.

Thanks are due to Drs J. T. Boyd, J. W. N. Duerden and L. A. Hardy for help in locating patients with farmer's lung in Ayrshire; Dr J. Lacey for providing a Type culture of M. faeni; the late Dr I. G. Murray for providing FLH antigen; Dr D. Parratt for results of the fluorescent antibody test; and in particular the farming personnel for their cooperation. The study was supported by a grant from the Medical Research Fund of the Secretary of State.

\section{References}

Andersen, A. A. (1958). New sampler for the collection, sizing and enumeration of viable airborne particles. Journal of Bacteriology, 76, 471-484.

Barbee, R. A., Dickie, H. A., and Rankin, J. (1965). Pathogenicity of specific glycopeptide antigen in farmer's lung. Proceedings of the Society for Experimental Biology and Medicine, 118, 546-550.

Boyd, D. H. A. (1971). The incidence of farmer's lung in Caithness. Scottish Medical Journal, 16, 261-262.

Boyd, G., and Parratt, D. (1974). Improved diagnosis of farmer's lung using the fluorescent antibody technique. Thorax, 29, 417-420.

Cross, T. (1968). Thermophilic actinomycetes. Journal of Applied Bacteriology, 31, 36-53.

Cross, T., Maciver, A. M., and Lacey, J. (1968). The thermophilic actinomycetes in mouldy hay: Micropolyspora faeni sp.nov. Journal of General Microbiology, 50, 351-359.

Dick, H. M., Dawson, C. O., and Campbell, J. D. (1973). Farmer's lung: a comparison of simple diagnostic techniques and antigen preparation in human and bovine disease. Clinical Allergy, 3, 209-216.

Faux, J. A., Holford-Strevens, V., Wells, I. D., and Pepys, J. (1970). 'False positive' precipitation reactions to extracts of organic dusts due to a teichoic acid from $S$. aureus. Clinical and Experimental Immunology, 7, 897-902.

Festenstein, G. N., Lacey, J., Skinner, F. A., Jenkins, P. A., and Pepys, J. (1965). Self-heating of hay and grain in Dewar flasks and the development of farmer's lung antigens. Journal of General Microbiology, 41, 389-407.
Gordon, M. A., Almy, R. E., Greene, C., and Senton, J. W. (1971). Diagnostic mycoserology by immunoelectroosmophoresis; a general, rapid and sensitive microtechnic. American Journal of Clinical Pathology, 56, 471-474.

Gourley, C. A., and Braidwood, G. D. (1971). The use of dust respirators in the prevention of occurrence of farmer's lung. Transactions of the Society for Occupational Medicine, 21, 93-95.

Grant, I. W. B., Blyth, W., Wardrop, V. E., Gordon, R. M., Pearson, J. C. G., and Mair, A. (1972). Prevalence of farmer's lung in Scotland: a pilot survey. British Medical Journal, 1, 530-534.

Hapke, E. J., Seal, R. M. E., Thomas, G. O., Hayes, M., and Meek, J. C. (1968). Farmer's lung. A clinical, radiographic, functional and serological correlation of acute and chronic stages. Thorax, 23, 451-468.

Hollingdale, M. R., and Murray, I. G. (1974). Antibody response in farmer's lung disease. In Aspergillosis and Farmer's Lung in Man and Animal, p. 280. Edited by R. de Haller and F. Suter. Hans Huber: Bern, Stuttgart and Vienna.

Morgan, D. C., Smyth, J. T., Lister, R. W., and Pethybridge, R. J. (1973). Chest symptoms and farmer's lung: a community survey. British Journal of Industrial Medicine, 30, 259-265.

Nonomura, H., and Ohara, Y. (1971). Distribution of actinomycetes in soil. $X$. New genus and species of monosporic actinomycetes. Journal of Fermentation Technology, 49, 895-911.

Ouchterlony, O. (1953). Antigen-antibody reactions in gels. Acta Pathologica et Microbiologica Scandinavica, 32, 231-240.

Parratt, D., and Peel, J. A. (1972). A fluorescent antibody test in the diagnosis of farmer's lung. Journal of Clinical Pathology, 25, 846-849.

Parratt, D., Nielsen, K. H., Boyd, G., and White, R. G. (1975). The quantitation of antibody in farmer's lung syndrome using a radioimmunoassay. Results of a clinical survey and comparison of three serological methods. Clinical and Experimental Immunology, 20, 217-225.

Pepys, J., and Jenkins, P. A. (1965). Precipitin (FLH) test in farmer's lung. Thorax, 20, 21-35.

Pepys, J., Jenkins, P. A., Festenstein, G. N., Gregory, P. H., Lacey, M. E., and Skinner, F. A. (1963). Farmer's lung. Thermophilic actinomycetes as a source of 'farmer's lung hay' antigen. Lancet, 2, 607-611.

Pepys, J., Riddell, R. W., Citron, K. M., and Clayton, Y. M. (1962). Precipitins against extracts of hay and moulds in the serum of patients with farmer's lung, aspergillosis, asthma and sarcoidosis. Thorax, 17, 366-374.

Raper, K. B., and Fennell, D. I. (1965). The Genus Aspergillus. The Williams and Wilkins Co.: Baltimore.

Smyth, J. T., Adkins, G. E., Lloyd, M., Moore, B., and McWhite, E. (1975). Farmer's lung in Devon. Thorax, 30, 197-203.

Wardrop, V. E. (1974). Studies on the microflora of farm environments associated with farmer's lung disease. PhD Thesis. University of Edinburgh. 